\title{
Surgical strategy for an anomalous origin of the right coronary artery
}

\author{
C Park', J Lee, Y Jun, C Choi, K Son, K Park \\ From 23rd World Congress of the World Society of Cardio-Thoracic Surgeons \\ Split, Croatia. 12-15 September 2013
}

\section{Background}

According to the recent guidelines, revascularization is recommended (class I) for the symptomatic patients of an anomalous origin of the right coronary artery. However, the long-term outcome of several operations is not fantastic due to their pros and cons. We sought to determine whether multidetector computer tomography (MDCT) coronary angiography would be a good preoperative clue for surgical strategy.

\section{Methods}

Between 2007 and 2013, 5 patients underwent unroofing or coronary bypass. For 2 patients, failure of unroofing inevitably led to bypass with saphenous vein during the operation. Thereafter, anatomical details of proximal right coronary artery (pRCA) were reviewed through the preoperative MDCT retrospectively.

\section{Results}

All 5 patients (three females, age 13 - 63 years) survived asymptomatically during the follow-up period (30 81 months). The surgical intervention included unroofing in 2 patients (unroofing group), RITA bypass in 1 and bypass with saphenous vein in 2 (the native vessel was inevitably taken down: SV group). We measured the average diameters of the portion where RCA takes off from aorta (D1), diameters of the widest part of the pRCA (D2) and the thickness of aortic mural $\operatorname{roof}(\mathrm{H})$. D1 of the unroofing group $(3.5 \mathrm{~mm})$ was wider than that of the SV group $(1.9 \mathrm{~mm})$ and there was higher D1/D2 ratio in the unroofing group.

\section{Conclusion}

The RCA diameter around the area where the RCA takes off from aorta can be an efficient clue to choosing the operative technique. It would be desirable to decide the operative modality after evaluating the anatomical feasibility through MDCT.

Published: 11 September 2013
Submit your next manuscript to BioMed Central and take full advantage of:

- Convenient online submission

- Thorough peer review

- No space constraints or color figure charges

- Immediate publication on acceptance

- Inclusion in PubMed, CAS, Scopus and Google Scholar

- Research which is freely available for redistribution
() Biomed Central

\footnotetext{
* Correspondence: cdgpch@gilhospital.com

Department of Thoracic and Cardiovascular Surgery, Gachon University, Gil
} Hospital, Incheon, Korea

C 2013 Park et al; licensee BioMed Central Ltd. This is an Open Access article distributed under the terms of the Creative Commons 